\title{
Challenging the Sovereign: Three Types of Early Modern Federal Theory*
}

Jan Smolenski

The fact that the term 'federation' in the social sciences is conceptually identified with the federal state (see, e.g.: Davis 1978; Elazar 1987; Stepan, Linz, and Yadav 2011; Watts 1998) is a symptom of a broader issue diagnosed by Jean L. Cohen as the domination of the statist paradigm in the academic treatment of federalism (cf. Cohen 2012, 11, 82). Accordingly, the studies of federalism are either treated within the context of the internal ordering of a state (here the concept of the federal state is in focus) or within the realm of international relations (here confederal treaty organizations of states are of interest). ${ }^{1}$ This state-centered focus reduces federalism to the administrative issue of the degree of centralization or a mere international agreement. More importantly, it obscures the fact that the political form of the modern federation and corresponding federal theories ${ }^{2}$ emerged in early modern Europe as a response to the crisis of the preWestphalian international order and as an alternative to the state and corresponding theories of sovereignty. (Cohen 2012, 88; Riley 1976, 18; Spruyt 1996; Forsyth 1981)

\footnotetext{
*Academic work is never an individual enterprise. I owe my thanks to my departmental colleagues Sara Gebh and Peter Galambos whose comments helped to improve this paper. I also want to thank an anonymous reviewer for their challenging questions, remarks, and comments. I am also grateful Manuela Badilla Rajevic for her last look at the paper.

1 E.g.: Carl J. Friedrich operates with this dualism in his treatment of federal theories and practices (Friedrich 1968); in his analysis of ancient leagues, Edward Freeman compares them to the US federal model (Freeman 1893); Patrick Riley assesses early modern theories of federalism according to their conformity to the form of the federal state (Riley 1976).

2 In this paper I treat political theories (whether of federalism or sovereignty) as a form of political practice.

3 Even American federation, considered a paradigmatic example of a federal state, was initially established as an alternative to the political form of the state. (Cohen 2012, Forsyth 1981)
} 
Certain scholars, most notably Carl Schmitt (2008), Murray Forsyth (1981), and Jean Cohen (2012), distinguish the federation form the federal state on the one hand and from the mere treaty-based international alliance on the other. Forsyth calls the federation (or, in his terminology: the federal union) "a union of states in a body politic". (Forsyth 1981, 7) For Schmitt, the federation is a "a permanent association ... through which the comprehensive status of each individual federation member in political terms is changed in regard to the common goals." (Schmitt 2008, 383-384) In Cohen's words, the federation is a "political and legal form for non-state composite polities that bridge the domestic/international divide without renouncing the discourse of sovereignty for member states and which are not imperial formations." (Cohen 2012, 82) Although motivated by different normative and political concerns, ${ }^{4}$ all three scholars have acknowledged that federal unions/federations are sui generis constitutional political forms. The aim of this paper is to contribute to the debate on federalism and federations beyond the statist paradigm. In contrast to these three authors, however, I do not attempt to offer a general theory of the federation. Rather, my aim is to present the variety of early modern federal theories as alternatives to the modern state and state sovereignty, grouped in three ideal types, and highlight significance of these differences.

The formation of the state proceeded through simultaneous centralization of power by eliminating internal competitors by aspiring princes on the one hand, and emancipation from the universal authorities of the Empire and Papacy on the other. This process was accompanied by the development of the absolutist Bodinian-Hobbesian theory of sovereignty. The effects of this process were 1) a threat to autonomy of sub-state units as a result of progressive development of organ sovereignty; 2) unstable international environment with constant possibility of war and resulting threat to security and survival of units (in particular small units); and 3) the disempowerment of the population as a correlate of the empowerment of the sovereign organ.

4 Carl Schmitt dismisses the federation as a political form plagued by internal contradictions and for this reason only a transitory form between either larger state or multiplicity of states. Jean Cohen, by contrast, sees in the federal union a possible and desirable answer to the contemporary challenges to state sovereignty posed by the processes of globalization. Forsyth, on his part, is mostly concerned with demonstrating its distinctiveness from the state and treaty-based organizations of states. 
The criterion for the classification is the effect that the theories respond to. ${ }^{5}$ The first ideal type (for the purposes of this paper named sovereignty relativizing federalism) consists of de-absolutization of organ sovereignty by means of introducing territorial intermediary bodies mediating between subjects and central power (internal deabsolutization), or subjecting the central authority to external higher power in order to provide avenues for appeals of sovereign's decisions (external de-absolutization). The second ideal type, concerned with the security in the international system, pools sovereignty (hence sovereignty pooling federalism) in a form of defensive or pacific federation in order to constitutionalize relations among states. The third type, developed together with the justifications of the right to rebellion, ${ }^{6}$ redefines sovereign power as power to constitute common authority and locates it in the collective body of the people; importantly, the act of constitution is understood as consensual coming together of territorial communities (hence bottom-up federalism). Additionally, these three ideal types also differ in regard to the criteria of evaluation for federal arrangements and normative implications of each of the types.

The argument of the paper proceeds as follows. In the first section I present the process of the formation of the state and the three effects to which theories of federalism responded: the rise of organ sovereignty, competitive geopolitical environment governed by the imperative of size, and the emergence of the state as independent from society. In the following three sections I present the three ideal types. In the concluding section, I draw implications for our thinking about federalism.

5 A note on the selection of authors: Given the aim of the paper, I will limit myself to early modern European authors, disregarding the American contribution to federal theory as well as theories developed around and after the French Revolution in Europe. For reasons of limited space I concentrate on two authors per type who contribute most to my argument. The first ideal type will be discussed through Montesquieu and Leibniz, the second one through Pufendorf and Rousseau, and the third one through Stephanus Junius Brutus, the Celt1 and Johannes Althusius. 'Stephanus Junius Brutus, the Celt' is a pseudonym of a French author of Vindiciae Contra Tyrannos. Although the tract is most often attributed to Philip Mornay there is no definitive proof.

6 It is common to attribute the invention of the concept of constituent power to Emmanuel-Joseph Sieyes. Nonetheless, although it is true the term 'pouvoir constituant' was used for the first time most probably by him, already in 1660 George Lawson wrote of the "power to constitute." (Lawson 1993, 47) Moreover, the distinction between the constituting and the constituted and the implication of the superiority of the former over the latter is present in the writings of the Monarchomachs and the logic of this distinction can be traced as early as the first half of the fourteenth century when it appears in the writings of Marsilius of Padua. (see: Kalyvas 2013) 
The rise of the state and state sovereignty

The formation of states and the corresponding theories of sovereignty were institutional and theoretical responses to the decline of the Medieval European political order of Respublica Christiana. This medieval order rested on a complex hierarchy of personal obligations between princes and nobles in which personal privileges and land ownership were the basis of public right. The apex of this hierarchy were the Pope and the Emperor, the ecclesiastical and temporal heads of the order, respectively, as powers claiming universal authority. (e.g. Poggi 1978; Philpott 1995, 360-361) This essentially creedal unity of Respublica Christiana was undermined by the Reformation. The religion-based universal authority of the Pope was questioned. Doctrinal differences antagonized holders of public powers and resulted in what Carl Schmitt has called European civil wars (Schmitt 2006).

The modern state and the corresponding concept of sovereignty was a response to the resulting social disorder. (Hinsley 1986, 126) The process of state making, as shown by Charles Tilly, proceeded through the centralization of power in the hands of the monarch and entailed the gradual elimination of autonomous seats of power and their military capacity within the claimed territory. (Tilly 1985) This monopolization of violence was supplemented by the creation of the bureaucratic apparatus capable of extracting resources necessary for this struggle without relying on local magnates as agents. In short, this process signified the dismantling of the intermediary bodies mediating between the central ruler and the subjects.

Absolutist theories of sovereignty were developed most notably by Jean Bodin and Thomas Hobbes to give this process ideological justification and theoretical legitimacy? Bodin defines sovereignty as "the absolute and perpetual power of a commonwealth... - that is, the highest power of command." (Bodin 1992, 1) Hobbes (Hobbes 1996) adopted this definition but liberated the power of sovereignty from constitutional and divine law constraints, still present in Bodin's theory, effectively making the sovereign power "unlimited, illimitable, irresponsible and omnipotent". (Hinsley 1986, 143) This difference aside, for both of them sovereignty is necessarily vested in the supreme organ

7 While analytically distinguishable, the formation of absolute monarchies and the formation of states in Early modern Europe were historically interrelated processes. For this reason, I treat them here together. 
of the state and is independent from the collectivity over which it rules. (see: Skinner 1989, 2002) It is repressive, commanding, and top-down. (Kalyvas 2005, 226-227) Consequently, not only the validity of all laws, including customary laws, within a territory but also the existence of all other institutions and possible autonomous loci of power between the sovereign and individual subjects is dependent on the sovereign's will.

This internal sovereignty is logically related to external sovereignty understood as independence. According to both Bodin and Hobbes, sovereignty also means impermeability to external jurisdictional claims. This effectively transposed the Hobbesian state of nature from the relations between individuals to the relations between states. The sovereign cannot be bound by law and any self-limitation is completely voluntary and can be terminated at will. In practical terms, external sovereignty meant jus belli and the 'right' to participate in international treaty making as equal with other sovereigns. (see: Cohen 2012, 26) In other words, while absolutist sovereignty was used to justify concentration of power as the sine qua non of internal order, it created unstable external environment. Moreover, as the distinction between the internal and external was not as clear at the threshold of the modern age, rulers attempting to centralize power perceived other princes as competitors in their quest for the monopoly of violence over a territory whereby the logic of 'internal pacification' extended into the logic of war. As Tilly concisely put it, "In these circumstances, war became the normal condition of the international system of states and the normal means of defending or enhancing a position within the system of states" (Tilly 1985, 184).

This process of state formation in Europe had three important effects already at the threshold of political modernity. The first effect is the gradual establishment of state sovereignty understood as organ sovereignty. This effect has its internal and external facets. Internally, it is associated with the elimination of the bodies capable of mediating between the sovereign and subjects and possibly moderating the impact the former had over the latter. Externally, by instituting the sovereign as the ultimate decision-maker, it eliminates any avenues for appeal against the decisions of the sovereign organ. The second effect is the normalization of war and conquest as a tool of state formation. The threat of war in the nascent state system could be averted only by preventive strikes or by deterrence of potential competitors. Given such competitive geopolitical environment and the related imperative of size, small polities are particularly threatened and 
vulnerable. The third effect is the emergence of the state, both as a concept and in practice, as the pacifier of social conflicts, independent from the society over which it exercises power. Crucially, the legitimacy of the state is not grounded in the community over which it rules but from its quality as sovereign, making any kind of resistance $a$ priori illegitimate.

It is important to note that the absolutist state sovereignty was not a description of reality at the threshold of political modernity. (Vincent 1987, 75) Rather, it formed the theoretical and ideological basis for the absolutist state formation. The sovereign modern state was invented before it was implemented. (Ruggie 1993, 166) It was forged in ideological, political, and military struggles with competing ideas regarding the organization of political power, federal ideas in particular. In what follows, I present three (ideal) types of early modern federal theory as responses to these three effects.

\section{Challenging Organ Sovereignty: Sovereignty Relativizing Federalism}

The absolute quality of emerging state sovereignty and its location at the apex of state power (organ sovereignty) had the internal effect of a gradual elimination of intermediary bodies as autonomous loci of power and the external effect of making the state impermeable for jurisdictional claims from without. It subjects individuals directly to the power of the sovereign on the one hand, and makes the decisions of the sovereign ultimate and unappealable. In response to these interrelated effects (for the purpose of classification taken as one combined effect), federal theory drew on the medieval and premodern experience to postulate the desirability of intermediary bodies and undermine the necessity of the absolute quality of sovereignty. To illustrate the former, I discuss federal elements in Montesquieu's discussion of the monarchy and Gothic constitutionalism; to reflect on the latter I turn to the work of Leibniz.

Centralization of power, particularly the one in France under Bourbons, had for Montesquieu despotic potential and features. (e.g.: Montesquieu 1989, 5.10.56) ${ }^{8}$ The reason for this was that since in monarchy "the prince is the source of all political and civil power," (Montesquieu 1989, 1.4.17) it requires a class of nobles with their statusbased privileges and organized in mediating bodies like parliaments to prevent this form 
of government from degenerating into despotic rule. The English, who also abolished privileges of the nobles, were nonetheless able to maintain their liberty only because their constitution was in fact republican under the guise of monarchy. (see: Montesquieu 1989, 5.19.70) Yet, despite Montesquieu's admiration for the separation of powers in the English system, he notes that if the English were to lose their liberty, "they would be one of the most enslaved peoples on earth." (Montesquieu 1989, 2.4.19) Thus, in spite of the separation of powers, the English system of parliamentary sovereignty carried a potential for despotism as it depended on a precarious balance between the Parliament and the monarch (see: Mosher 2000, 180-181).

Both French absolutism and English parliamentary sovereignty were successors of Gothic constitutions which, according to Montesquieu, were "the best kind of government men have been able to device." (Montesquieu 1989, 11.8.168) As Lee Ward argues, Montesquieu saw elements of Gothic constitutionalism as capable of mitigating the potential for despotism even in the English constitution. (Ward 2007) ${ }^{9}$ The Gothic constitution of the French kingdom consisted of three main elements. The first element is that it encompassed a multiplicity of groups who were connected with the monarch through reciprocal rights, retained their significant autonomy within the kingdom, and even participated in the election of the ruler. The second is that the local hereditary nobles gathered in provincial assemblies and were entrusted with codification and implementation of provincial laws. As Ward notes, "[t]he impact of this institution was to structure the French legal system on the basis of overlapping and conjoint jurisdictions in which the crown and the nobility, the center and the regions shared power." (Ward $2007,566)$ The third element is the organization of local powers into institutions mediating and buffering royal power. (Ward 2007, 567) In his rooting of these three elements in the privileges of nobility, Montesquieu assumed a reactionary position defending the aristocratic prerogatives against the centralizing absolutist monarchy. (see: Althusser 2007) Nonetheless, to the extent that the elements of Gothic constitutionalism can be understood also as legal pluralism, territorial division of power, and intermediary powers with legitimate standing independent from central authority (rather than just

9 In this section I am very indebted to Lee Ward's illuminating and ingenious interpretation. According to Ward, Montesquieu's main contribution to federal theory is not to be found in the short discussion of the federal republic (Book 9, Chapters 1-3 in The Spirit of the Laws), but in his discussion of the Gothic constitution of the French kingdom. In this respect, I do not claim originality. 
layers of status-based social orders) it resembles modern federalism as self- and shared rule.

Leibniz applies similar logic of de-absolutization of sovereignty to external relations. Refuting Hobbes, Leibniz denies the reality of the absolutist conception of sovereignty by stating that it empirically does not exist "neither among civilized peoples not among barbarians". (Leibniz 1988a, 120) Rather, sovereignty, according to him, properly means "territorial supremacy" or "territorial hegemony". Internally, the mark of sovereignty is the coercive power "readied not against a few stubborn persons, but against an entire community" (Leibniz 1988a, 115) in order to compel subjects to perform their duties owed to the territorial lord. Nonetheless, this supremacy in relation to subjects does not exclude limitations on what the sovereign can legitimately demand from them. (Leibniz 1988a, 116) Externally, the mark of sovereignty is freedom from external tutelage and the capacity to engage in international politics: "Those are counted among sovereign powers, then, and are held to possess sovereignty, who can count on sufficient freedom and power to exercise some influence in international affairs, with armies or by treaties." (Leibniz 1988b, 175) Just as in the case of internal sovereignty, it does not imply absolute power as the one who is considered sovereign "may perhaps be limited by the bonds of obligation toward a superior and owe him homage, fidelity and obedience" (Leibniz 1988b, 175).

This relativization of sovereignty allows Leibniz to develop the concept of a union of states as a body that cannot be reduced to the sum of its members: "it is necessary that a certain administration be formed, with some power over the members; which power obtains as a matter of ordinary right, in matters of greater moment, and those which concern the public welfare. Here I say there exists a state.” (Leibniz 1988a, 117). For Leibniz, the Germanic Empire is an example of such a union where the majesty of the Empire defined as "the right command without being subject to command" (quoted in: Riley 1976, 27) is above the sovereign power of the princes. Despite this quality of imperial majesty, the power of the emperor was limited by the imperial Diet and prerogatives and privileges of territorial princes. (see: Leibniz 1988c, 183) The example of the Empire also shows why, for Leibniz, absolute sovereignty was undesirable: "in the Empire, subjects can plead against their princes, or their magistrates." (Leibniz 1988c, 
181) In other words, the existence of a higher power than that of the sovereign provides avenues to appeal the decisions of the direct ruler.

Leibniz's idea of sovereignty as mere territorial supremacy (and not the highest power) served to protect the rights of the lesser imperial princes in the international arena, ${ }^{10}$ but was rooted in the medieval understanding of political order, both internal and external, and in the desire to restore the Empire as a universal temporal power. (Riley 1976, 25-26) In this sense, Lebniz's position can also be considered "out of date" (Riley $1973,28)$ or simply reactionary. Nonetheless, to the extent that he understood the Empire as a multiplicity of constitutional forms existing within a larger constitutional form, and not mere princely patrimonies within a feudal structure of personal loyalties, his ideas resemble non-state federalism as well.

In sum, Montesquieu's federalism de-absolutizes the power of the monarch through territorial dispersion and independently existing institutions, undermining organ sovereignty, whether that of the monarch or that of the parliament. Leibniz's does the same but maintaining a higher temporal power over that of the sovereign. It is important to remember that for both Leibniz and Montesquieu, the development of the quasi-federal arrangements of the Empire and the Frankish kingdom under Gothic constitution was a process of historical devolution of power in previously more centralized polities and not created through a founding treaty. (respectively: Leibniz 1988c, 182; Montesquieu 1989, passim, e.g. 31.1.670-671) In this sovereignty relativizing federalism, the federal principle is primarily enacted by sharing governmental functions between the center and regions in order to mitigate possible arbitrariness related to the concentration of power. In other words, it is about dispersing power and channeling its exercise through different institutional and territorial units. Consequently, in this case the criterion of evaluation of the federation is how efficiently it de-absolutizes sovereign power and mitigates arbitrariness. Thus, normatively, it does not matter whether a federation was created through decentralization or through coming together, or to what extent it does away with hierarchies of power. Origins are irrelevant for the federation's goals. What matters

10 Leibniz wrote Tractatus de jure suprematus ac legationis principum Germaniae (more commonly known as De Suprematu Principium Germaniae or Caesarinus Fürstenerius, the latter after the pseudonym under which Leibniz wrote the work), his most important work on the constitution of the Germanic Empire, serving as a counsellor for the Duke of Brunswick. The aim of the work was to justify the duke's claim to participation in Nijmegen peace negotiations from which the duke was excluded despite his involvement in the preceding wars. (Nijman 2005, 11) 
is the creation of genuine checks on the center and avenues of appeal within the federation.

\section{Providing Security and Peace: Sovereignty Pooling Federalism}

Since in theory the sovereign state was released from its external obligations (save voluntary, hence unreliable, self-binding) and state formation proceeded through war and conquest, it created a competitive geopolitical environment in which the imperative of size influences the possibility of survival. Theorists of sovereignty pooling federalism have drawn from the experience of international treaty making in order to come up with the design of the coming together of several states that would combine not only the advantage of size with the preservation of independence but that would also make such arrangement sufficiently durable. The two most important theorists in this regard are Samuel von Pufendorf and Jean-Jacques Rousseau.

Pufendorf accepts the Bodinian-Hobbesian idea of state sovereignty as internally unitary and externally independent (cf. Eulau 1941, 657). Only these polities in which "the supreme Authority is exercis'd through all the parts of the State by one Will" (Pufendorf 1729,670 ) can be considered regular. He dismissed the Germanic Empire, a role model for Leibniz, as an "irregular" and "mis-shapen Monster" (Pufendorf 2007, 179). The charge of irregularity applies also to Montesquieu's Gothic constitutionalism to the extent that its intermediary bodies split the sovereign will. Yet, Pufendorf departs from Hobbes (and by extension Bodin) since he believes that federations, constitutionalized arrangements among states which he calls systems of states, ${ }^{11}$ can mitigate instability of international system. $^{12}$

The reason for entering a league is purely defensive against external threats to independence, i.e. a possibility of war and conquest (Pufendorf 1729, 682). Systems of states are more than just coalitions of states. The latter are based on contingent and temporary commonalities of foreign policy aims and are limited only to the mutuality of obligations within fulfilling these aims. The federation, by contrast, originates in a com-

11 Pufendorf distinguishes two kinds of systems: personal unions and leagues (federations). In this paper I am interested in the latter.

12 It is important to note that Pufendorf departed in one important aspect from Hobbesian idea of sovereignty as absolute power. For the former, the creation of a state consisted of two contracts, the contract of society and the contract of government, which may result in constitutional limitations on power of the sovereign. 
pact and consists of states which "are, by some special Band, so closely united, as they seem to compose one Body, and yet retain each of them the sovereign Command in their respective Dominions" (Pufendorf 1729, 681). It creates a perpetual union in which states oblige themselves to exercise parts of sovereignty, primarily those related to foreign policy, jointly with the common consent of the members of the league (Pufendorf 1729,82$)$. Conflicts between the members are supposed to be arbitrated by other confederates who do not have stakes in these disputes. At the same time, whatever is not specified in the initial compact as necessary for fulfilling the common purpose, is supposed to remain within the residual powers of states.

Because the league originates in a compact of independent states and creates a "Union or Concurrence of Wills" rather than one superior will, Pufendorf introduces the requirement of unanimous decision-making (Pufendorf 1729, 684). Majority decision making can result in a situation in which the minority is compelled to act against its will. Such an outcome would undermine the purpose for which the league is established in the first place (to guarantee independence of federating parties). Since the initial foe$d u s$ constitutionalizes the relations of co-ordination among the federating states and not subordination, the legitimacy of collective decisions is necessarily based on consent. If a member persistently refuses to follow the majority and in this way endangers the league, sanctions are permitted; but, rather than being a form of federal intervention, juridically they are "the same Methods of Redress, as they who hve [sic!] in a Condition of natural Liberty are allow'd to use against the Violaters of Faith and Contract" (Pufendorf 1729, 685), as if the federal compact with the offender were null and void.

Essentially, a system of states provides an institutional framework with three main aims: to provide security by pool resources against common external threat, to peacefully adjudicate conflicts among the federated states, and to provide equality of the states in governing common affairs through the principle of unanimous consent. The requirement of consent, however, poses the limit of the perpetuity of the union. ${ }^{13}$ Because the union has a very specific aim, then if "some Confederates ... hope to receive more Advantage by a Separation, than they could expect under a Conjunction, and apprehend their Allies to be rather a Burthen to them, than as Assistance" (Pufendorf 1729, 685), they may voluntarily leave the union. Secession, thus, is a logical consequence of the

13 Perpetuity of the union means that its raison d'etre in principle temporarily transcends any specific foreign policy goals but a universally valid goal of securing independence. 
contractual origin of the union and its continuous existence is based on the principle of consent.

Rousseau, like Pufendorf, sees the solution to the problem of war in federal arrangements. He acknowledges that the lack of uniformity and clear principles of European international law at the time of his writing reduces in practice the conduct between states to the right of the stronger and renders interstate treaties "a temporary truce rather than a real peace" (Rousseau 2005, 63). ${ }^{14}$ Thus, the European Federation is supposed to "unite nations by bonds similar to those which already unite their individual members, and place the one no less than the other under the authority of the Law" (Rousseau 2005, 60). Institutionally, the European Federation of Rousseau is not that different from Pufendorf's system of states. ${ }^{15}$ As he specifies in the five fundamental articles of the union, the federation shall, first of all, originate in a compact between sovereigns. The legislative powers shall be vested in a Diet in which each power shall have one vote irrespectively of its size, power, or contributions and in which each shall in turn assume presidency. It shall have a federal budget to cover common expenses. Rousseau also says that a member state can be "put to ban" and "proscribed as public enemy" (Rousseau 2005, 68) if its behavior amounts to breaking the constituent treaty.

Where Rousseau departs from Pufendorf is the relations between the Federation and the constituent states. This is already visible in what the former considers the destructive behavior which includes refusal to "execute the decisions of the Alliance" (Rousseau 2005, 68). The decisions of the Federation can go against the will of individual states because Rousseau accepts majority decision making in the federal Diet (with the exception of amending the five articles, which requires unanimity). Additionally, although the offender is proscribed as a public enemy, "all the Confederates shall arm and take the offensive ... and they shall not desist until ... [the offender shall have] carried out the decisions and order of the Diet" (Rousseau 2005, 68). Such action is in fact a federal intervention rather than a nullification of the contract with the offender. Additionally, despite the contractual beginning of the Federation, Rousseau denies the right

14 This argument is an element of Rousseau's political realism which only grew with time. While he celebrated the plan of perpetual peace in his earlier writing, in the ones produced later he deemed it unrealizable. The problem was not with the project itself but with the general character of the initial arguments in favor of federalism. The implementation the project requires appealing directly to specific individual interests that particular rulers have at a particular time. (Forsyth 1981, 92)

15 The following two paragraphs are based on the five articles of the federation. (Rousseau 2005, 68- 
to exit. Authentic federation is a "genuine Body politic" with powers to pass binding laws, with coercive power to enforce them, and with enough strength to make "it impossible for any member to withdraw at his own pleasure the moment he conceives his private interest to clash with that of the whole body" (Rousseau 2005, 67). ${ }^{16}$

Rousseau gives three reasons why such empowerment of the Federation vis-à-vis its members does not diminish their sovereignty. First, the members participate in collective lawmaking as equals and, as Rousseau notes, "there is all the difference in the world between dependence upon a rival and dependence upon a Body of which he is himself a member and of which each member in turn becomes a head" (Rousseau 2005, 74). In other words, although the substance of particular decisions might contradict the wills of individual states at particular times, the procedure of arriving at these decisions was established through consent by a founding treaty. Second, further limits on the substance of decisions are imposed by the requirement of consent to change provisions of the founding treaty. ${ }^{17}$ Third, the body of equals protects the borders and the internal constitutional order of each member against the external and internal threats (these including domestic insurrections) by entrenching these protections in the founding treaty, thus securing the power of incumbent princes (Rousseau 2005, 68, 71-72).

Nonetheless, there are important commonalities. In the case of sovereignty pooling federalism, the federal principle is enacted by the creation of a constitutional form aiming at pooling resources necessary for common defense and acting jointly in the sphere of foreign policy, peacefully adjudicating conflicts among member states, while maintaining the sovereignty of each member. This type presupposes already existing states that can come together. The criterion of evaluation is to what extent these possibly conflicting aims can be institutionally reconciled. Origins matter to the extent that they are logically presupposed by the aim of the federation to maintain sovereignty of its member states. Given these aims, this type normatively implies that the consensual coming

16 The difference between Rousseau and Pufendorf in regard to unanimity in the Diet and right of exit is related to the role of war in the argument of each of them. For Pufendorf war is an event that happens, an external possibility in the face of which the federation is supposed to provide security (through common protection if not through deterrence). For Rousseau, however, war is an existential condition of the state system absent of overarching enforceable law. Consequently, what needs to be eliminated are the conditions of possibility of war as such.

17 This marks the fundamental difference between federal legislation and legislation within a unitary polity in Rousseau's thought. In the case of the latter, regular legislation and constitutional change are indistinguishable while the principle of unanimity clearly separates revisions of the constitutional treaty from the federal legislation. 
together of equals will be reflected in the decision making and institutional operations of the federation. Foundational consent is a crucial element as it has behavioral and constitutional implications, most of all equality of all parties and their equal share in the federal council. Moreover, this foundational consent translates into the requirement of unanimity at least in changing foundational constitutional articles. Thus, sovereignty in this type is not de-absolutized but pooled for common purposes.

De-autonomizing the state: Bottom-up Federalism

The third effect of the rise of the sovereign state is the disempowerment of the people vis-à-vis the ruler as a correlate of the emergence of organ sovereignty. In this regard the third type of federal theories responds to a similar concern as the sovereignty relativizing federalism. Historically, however, the development of the third type of federal theory was accompanied by the early modern rebellions against these centralizing tendencies empowering the center at the expense of the peripheries. These theories emerged together with justifications of rebellion and tyrannicide. Thus, unlike the first type, theories of bottom-up federalism do not relativize sovereignty, but rather vest it in the collective body of the people, redefine it, and use as a principle to reimagine political community. The works discussed in this section are Vindiciae Contra Tyrannos by Stephanus Junius Brutus, the Celt (pseudonym) (Junius Brutus, the Celt 2003), and Politica Methodice Digesta by Johannes Althusius (Althusius 1995).

Vindiciae was written in the aftermath of the St Bartholomew's Day Massacre (1572) in the middle of the French religious wars and is the most famous of the Monarchomach tracts justifying the right of rebellion and tyrannicide. The right of resistance is based on Junius Brutus' conception of popular sovereignty: "the people constitutes kings, confers kingdoms, and approves the election by its vote" (Junius Brutus, the Celt 2003, 68). Popular sovereignty is understood here as constituent power, i.e. the power of the collectivity to jointly establish its political form. ${ }^{18}$ Because the people is the subject of the constituent power and the king only a constituted power, "the whole people [Populus universus] is more powerful" for "one who is constituted by another is held to

18 For the explanation of my use of the concept of constituent power, see note 5. 
be lesser; and one who receives his authority from another is inferior to his appointer" (Junius Brutus, the Celt 2003, 74).

The act of constituting the king is described in terms of a covenant (in latin foedus) formalized in the exchange of oaths between the king and the people, the former pledging just rule and protection and the latter obedience. However, the oath of the people is conditional. The people owes the king obedience only as long as the king keeps his oath. Kings are constituted for a specific purpose: to deliver justice internally and command armies for external protection (Junius Brutus, the Celt 2003, 93). Effectively, the king is a mere supreme magistrate and not a sovereign. If the king violates the terms of the covenant, he commits high treason and the people may legitimately resist and forcefully depose the tyrant (Junius Brutus, the Celt 2003, 156). Rebellion is an enactment of constituent power of the people.

It is important to note, that by the people Junius Brutus means representatives "who have received authority from the people - the magistrates, clearly, who are inferior to the king and chosen by the people, or constituted in some other way" (Junius Brutus, the Celt 2003, 46) and only through them popular sovereignty can be enacted. Some of these magistrates, called the officers of the kingdom and the monarch's partners in rule, are responsible for the whole kingdom, others only for its parts (Junius Brutus, the Celt 2003, 85-86). The duty of the latter is "to protect the people within the extent of their jurisdiction" (Junius Brutus, the Celt 2003, 86). If the former fail to protect the whole kingdom against tyranny, the latter should do it in their respective provinces. Ellen Meiksins Wood sees it as an indication that, under the guise of the right to rebellion, the Huguenots defended withering away sectional privileges of lower, provincial sectors of the French nobility which was highly overrepresented among the French Calvinists (Wood 2012, 155 and further). Irrespective of the material interest behind it, this insistence on the role of provincial magistrates in protecting against tyranny led Junius Brutus to understand resistance (at least partially) in terms of secession: provincial magistrates should vindicate "that part of the kingdom over which they have assumed tutelage" and "expel him (the tyrant) from their borders [fines]" (Junius Brutus, the Celt 2003, 166).

Just as the general right of the people as a whole to resist the tyrant is justified by endowing the people with constituent power, the role of the provincial magistrates in 
resistance against the tyrant is justified through their participation as representatives of provinces in the foedus with the monarch. This introduces a federal element into the interpretation of the French constitution by the author of Vindiciae. Magistrates of regions or cities are not appointed by the king but constituted by the people of these parts of the kingdom (Junius Brutus, the Celt 2003, 84, cf. 46) and their duties mirror to some extent the duties of the king. Moreover, they represent their regions in the dealings with the monarch. Essentially, the kingdom as a whole is a compound polity united through the foedus of the people, represented as a whole by certain officers of the kingdom and through nobles representing its parts, with the supreme magistrate.

That Johannes Althusius was inspired by the tract by Junius Brutus is evident from frequent references to Vindiciae in Politica. In the latter work, written at a moment of relative peace, ${ }^{19}$ Althusius develops the bottom-up logic of federalism, incipient in Vindiciae, much further. It is already clear in his definition of politics as "the art of associating (consociandi) men for the purpose of establishing, cultivating, and conserving social life among them" (Althusius 1995, 17). He adds that "the efficient cause of politics is consent and agreement among communicating citizens" (Althusius 1995, 24). The emphasis on pledges given by the associates, tellingly called "symbiotes," to each other privileges horizontal relations over the vertical ones. Coming together is the very core around which his theory of politics is built. The process of associating unfolds in a consensual creation of communities, from a nuclear family to a universal commonwealth as the "human society develops from private to public association by the definite steps and progressions of small societies" (Althusius 1995, 39). In this process, smaller associations are creators and members of more comprehensive ones, and despite successive unions they maintain their integrity. At each step, the principle of governing the association is the same: the elected leader of the association is its administrator, is bound by the oath to attend to the welfare of the association, and is superior to each individual member but inferior to the association as a whole (e.g. Althusius 1995, 16, 41-

19 The first edition of Politica was published in 1603, after de facto (not yet de jure) success of the Dutch Revolt against the Spanish Hapsburgs (1585) and the conclusion of the French Wars of Religion (1598) but before the beginning of the Thirty Years' War (1618). The revised second and third editions were published in 1610 and 1614, respectively. This might explain why Politica in comparison to Vindiciae has much more systematic structure of a juridico-political treatise than a pamphlet.

The citations are from the abridged english translation of the third edition. 
$42,122) .{ }^{20}$ In each case, it is justified by the primacy of the constituting over the constituted, i.e. the principle of constituent power.

This formal definition of politics is developed into a grand design of a polity. In this design, Althusius distinguishes between private and public associations. The latter are constituted when the plurality of private associations (families, kinship groups, and collegia) living in the same place decides to associate and be governed by the same set of laws; the individual persons comprising the private associations that form the public association become its citizens (Althusius 1995, 39-40). These small communities (hamlets, villages, towns, and cities) associate into provinces; provinces in turn associate into a universal commonwealth. At the level of the province, less comprehensive associations are represented as members in provincial estates (Althusius 1995, 60). This structure is reproduced at the level of the commonwealth; it is supplemented, however, by the offices of ephors who resemble Junius Brutus' officers of the kingdom. The people through their representatives elect ephors who in turn elect the supreme magistrate. Ephors assist the supreme magistrate in fulfilling his obligations; in the case of attempts at tyranny they are supposed to lead resistance - general ephors at the level of the commonwealth and special ephors within territories entrusted to them.

Althusius expands the notions of federalism and popular sovereignty present in Vindiciae. Regarding the former, Althusius' design is not static but dynamic: the commonwealth is constituted through a series of acts of association initiated at the bottom, each subsequent act being an iteration of the first one on a larger scale. Just like Junius Brutus, he locates sovereignty in the people and understands it as constituent power (Elazar 1995, xlii; Hueglin 1999, 150), but he goes beyond Vindiciae in two respects. First, he extends the principle of constituent power to each act of associating since on each level more comprehensive associations depend on the consent on their constituents. For this reason he admits secession not only in the case of tyranny but also if a province does not benefit from the membership in the commonwealth (Althusius 1995, 197). Second, and related to the right of resistance: while following Junius Brutus he denies private individuals the right of rebellion, he nonetheless allows for the election of ad hoc ephors

20 The exception here is the head of the province as a member of the universal commonwealth, who is appointed by the supreme magistrate. Thomas Hueglin attributes this deviation from the principle to the political conflict Althusius was involved in as a syndic of Emden between the city and the count of Easter Frisia (see: Hueglin 1999, 36). 
to organize resistance (Althusius 1995, 195). As Thomas Hueglin accurately puts it: Althusius' federalism "means pluralization of governance among members of a commonwealth wherein all higher levels of authority are as a matter of principle constituted on the basis of consent and solidarity from below" (Hueglin 1999, 153). The effect is a bottom-up constituted multilevel structure of increasingly comprehensive associations in which more comprehensive associations are constituted by but do not exhaust less comprehensive ones. Nonetheless, despite these differences, in both Vindiciae and Politica, the federal principle is associated with popular sovereignty understood as constituent power and implies the bottom-up constitution of a compound polity. Additionally, in both cases rebellion is understood as secession and justified in terms of the primacy of the constituent over the constituted. In both cases central power normatively and logically depends on the coming together of smaller territorial units with independent source of legitimacy.

To sum up, in the case of bottom-up federalism, the federal principle is manifested in the bottom-up coming together of different groups as a means of constituting more comprehensive associations, which nonetheless are dependent on the less comprehensive ones. While similar to the founding foedus of the second type, this one is not limited to sovereign states but can include other political forms, like compound ones. The reason for this is that, unlike in the second type, sovereignty is not vested in each member separately and pooled, but jointly in all as constituent power. In this case, origins are fundamental, because they are the criterion of evaluation. Normatively, then, it implies the necessity of preserving the principles of the founding in the juridico-political structure by empowering the collectivity against the center to prevent usurpation and tyranny.

\section{Conclusions}

In the previous sections I presented three ideal types of federal theory as responses to the effects of the early modern development of the state and the corresponding absolutist theory of state sovereignty. In the case of each type, federation is a political form different from and an alternative to the sovereign state. Nonetheless, in each case, the federal principle of self- and shared rule is manifested differently. These differences 
matter to the extent that they inform us about the criteria of evaluation for federal arrangements and normative implications of each of the types.

There are at least two major stakes in this reconstruction. First, showing the early modern alternative to the state denaturalizes the political form of the state. The state has not simply developed from pre-modern forms of political organization. The proponents of the state won ideological and political struggles not only against the European ancien régime but also against proponents of alternative political forms. Presenting its early modern competitor (or, rather, competitors - about this in a moment) undermines the obviousness of the state, whether unitary of federal, whether standing alone or in alliance with others. Additionally, it opens up space for new questions, not only concerning how the alternatives were crowded out ${ }^{21}$ but also about the alternative itself. For example, investigated as "the path not taken" federation can serve as a basis for a normative critique of the state. It repoliticizes federalism, elevating it from the issue of administrative arrangements to issue of the political form, or, in other words, from a technical question to a question of the political principle.

The second stake has to do with the diversity of federal theories, specifically - the differences regarding the manifestation of federal principle, the criterion of evaluation, and the normative implications. Sovereignty relativizing federalism, as it is concerned with mitigating the power of the center, in a charitable reading is compatible with a liberal polity defending individual rights at the expense of not only central government but also popular participation, not unlike the American federation envisioned by the Founding Fathers (cf. Hamilton, Madison, and Jay 2003, The Federalist no. 10 and no. 63). In a more critical reading, it dangerously closely approaches an imperial formation. Sovereignty pooling federalism, concerned mainly with providing security for and maintaining sovereignty of the member states, is compatible with the conservative features of the German Bund, a union of monarchical states united in their aim to preserve the privileges of the rulers (cf. Forsyth 1981). Bottom-up federalism, by contrast, stressing the bottom-up process of federating and dependence of the higher level authorities on the lower level communities, seems more compatible with the multilayered system of wards

21 Even such insightful works on the development of the modern state like the ones by Gianfranco Poggi (1978), Tilly, or Jordan Branch (2014) answer only the question how the state was built against the pre-modern arrangements. The question how and why it defeated other political forms is rarely addressed - a notable exception here is Spruyt (1996). 
envisioned by Jefferson (1999) or Condorcet's (1976) constitutional proposal consisting of multiple levels and loci of participation. At the same time, first two types seem in principle much more stable than the rebellious third one. This diversity of federal arrangements introduces additional political question: not only either the state or federalism, but also which federalism. Thus, recovery of early modern theories federalism not only can enrich our thinking of federalism beyond the dominant dichotomy federal state-confederation of states but open our eyes to alternatives to the statocentric status quo.

\section{References}

Althusius, J 1995 Politica, Liberty Fund, Incorporated, Indianapolis.

Althusser, L 2007 'Montesquieu: Politics and History', in L Althusser Politics and History: Montesquieu, Rousseau, Marx, translated by Ben Brewster, Verso, London, New York.

Bodin, J 1992, On Sovereignty, edited by JH Franklin, Cambridge University Press, Cambridge, New York.

Branch, J 2014, The Cartographic State: Maps, Territory, and the Origins of Sovereignty, 1. edn, Cambridge University Press, New York.

Cohen, JL 2012, Globalization and Sovereignty: Rethinking Legality, Legitimacy, and Constitutionalism, Cambridge University Press, Cambridge.

Condorcet, JAN de Caritat marquis de 1976, 'On the Principles of the Plan Presented to the Convention', in Selected Writings, edited by KM Baker, Bobbs-Merrill, Indianapolis.

Davis, SR 1978, The Federal Principle: A Journey Through Time in Quest of Meaning, University of California Press., Berkeley

Elazar, DJ 1987, Exploring Federalism, University Alabama Press, Tuscaloosa.

Elazar DJ 1995, 'Althusius' Grand Design for a Federal Commonwealth', in J Althusius Política, Liberty Fund, Incorporated, Indianapolis.

Eulau, HHF 1941, 'Theories of Federalism under the Holy Roman Empire', The American Political Science Review vol. 35, no. 4, pp. 643-64.

Forsyth, MG 1981, Unions of States: The Theory and Practice of Confederation, Holmes \& Meier Publishing, New York.

Freeman, EA 1893, History of Federal Government in Greece and Italy, edited by JB Bury, Macmillan and Co, London, New York.

Friedrich, CJ 1968, Trends of Federalism in Theory and Practice, 1, edn., Frederick A. Praeger Publishers, New York.

Hamilton, A, J Madison, J Jay 2003, The Federalist Papers, edited by Clinton Rossiter, 1. edn., Signet, New York. 
Hinsley, FH 1986. Sovereignty. 2 edition. Cambridge Cambridgeshire; New York: Cambridge University Press.

Hobbes, T 1996, Leviathan, edited by Richard Tuck, Revised Student Edition, Cambridge University Press: Cambridge.

Hueglin, TO 1999 Early Modern Concepts for a Late Modern World: Althusius on Community and Federalism, Wilfrid Laurier University Press, Waterloo, ON.

Jefferson, T 1999, 'To Joseph C Cabell, February 2, 1816', in T Jefferson, Jefferson: Political Writings, edited by J Oldham Appleby and T Ball, Cambridge University Press, New York.

Junius Brutus, the Celt, S 2003, Vindiciae, Contra Tyrannos: Or, Concerning the Legitimate Power of a Prince over the People, and of the People over a Prince, edited by George Garnett, Cambridge University Press, Cambridge, New York.

Kalyvas, A 2005, 'Popular Sovereignty, Democracy, and the Constituent Power', Constellations vol. 12, no. 2, pp. 223-44.

Kalyvas A 2013, 'Constituent Power', Political Concepts, no. 3.1 (Winter), http://www.politicalconcepts.org/constituentpower/.

Lawson, G 1993, Politica Sacra et Civilis, edited by Conal Condren, Cambridge University Press, Cambridge, New York.

Leibniz, GW 1988a, 'Caesarinus Fürstenerius (De Suprematu Principium Germaniae)', in GW Leibniz, Leibniz: Political Writings, edited by Patrick Riley, 2. edn., Cambridge University Press, Cambridge, New York.

Leibniz, GW 1988b, 'Codex Iuris Gentium (Prefatio)', in Leibniz: Political Writings, 2. edn., Cambridge University Press, Cambridge, New York.

Leibniz, GW 1988c, 'Observations on the Abbé de St Pierre's "Project for Perpetual Peace"', in Leibniz: Political Writings, edited by Patrick Riley, 2. edn., Cambridge University Press, Cambridge, New York.

Montesquieu, C de 1989, Montesquieu: The Spirit of the Laws, edited by AM Cohler, BC Miller, and HS Stone, Cambridge University Press, Cambridge, New York.

Mosher, MA 2000, 'Monarchy's Paradox: Honor in the Face of Sovereign Power', in DW Carrithers, MA Mosher, and PA Rahe (red.) Montesquieu's Science of Politics: Essays on The Spirit of Laws, Rowman \& Littlefield Publishers, Lanham, Md.

Nijman, J 2005 'Leibniz's Theory of Relative Sovereignty and International Legal Personality: Justice and Stability or the Last Great Defense of the Holy Roman Empire', IILJ Working Paper 2004/2. History and Theory of International Law Series, Institute for International Law and Justice, New York University School of Law, New York, http://papers.ssrn.com/abstract=1560742.

Philpott, D 1995, 'Sovereignty: An Introduction and Brief History', Journal of International Affairs 48 (2): 353-68.

Poggi, G 1978, The Development of the Modern State: A Sociological Introduction, 1. edn., Stanford University Press, Stanford.

Pufendorf, S 1729, Of the Law of Nature and Nations, Walthoe, London. 
Pufendorf, S 2007, The Present State of Germany, Liberty Fund, Incorporated, Indianapolis.

Riley, P 1973, 'The Origins of Federal Theory in International Relations Ideas', Polity, vol. 6, no. 1, pp. 87-121.

Riley, P 1976, 'Three 17th Century German Theorists of Federalism: Althusius, Hugo and Leibniz', Publius, vol. 6, no. 3, pp. 7-41.

Rousseau, JJ 2005, 'A Lasting Peace through the Federation of Europe: Exposition and Critique of St. Pierre's Project', in D Karmis and W Norman (red.) Theories of Federalism: A Reader, Palgrave Macmillan, New York.

Ruggie, JG 1993, 'Territoriality and Beyond: Problematizing Modernity in International Relations', International Organization, vol. 47, no. 1, pp. 139-74.

Schmitt, C 2006, The Nomos of the Earth in the International Law of the Jus Publicum Europaeum, translated by GL Ulmen, Telos Press Publishing, New York.

Schmitt, C 2008, Constitutional Theory, Duke University Press, Durham.

Skinner, Q 1989, 'The State', in T Ball, J Farr, and RL Hanson (red.) Political Innovation and Conceptual Change, Cambridge University Press, Cambridge, New York.

Skinner, Q 2002, 'Hobbes and the Purely Artificial Person of the State', in Q Skinner, Visions of Politics, Vol. III, 1. edn., Cambridge University Press, Cambridge.

Spruyt, H 1996, The Sovereign State and Its Competitors: An Analysis of Systems Change, Princeton University Press, Princeton.

Stepan, A, JJ Linz, and Y Yadav 2011, Crafting State-Nations: India and Other Multinational Democracies, 1. edn., Johns Hopkins University Press, Baltimore.

Tilly, C 1985, War Making and State Making as Organized Crime', in P Evans, D Rueschemeyer, and T Skocpol (red.), Bringing the State Back In, Cambridge University Press, Cambridge.

Vincent, A 1987, Theories of the State, 1. edn., Basil Blackwell, Oxford, New York.

Ward, L 2007, 'Montesquieu on Federalism and Anglo-Gothic Constitutionalism', Publius: The Journal of Federalism vol. 37, no. 4, pp. 551-77.

Watts, RL. 1998, 'Federalism, Federal Political Systems, and Federations', Annual Review of Political Science, vol. 1, pp. 117-37.

Wood, EM 2012, Liberty and Property: A Social History of Western Political Thought from the Renaissance to Enlightenment, 1. edn., Verso, London, New York. 